\title{
ALLOCASUARINA CRASSA L. JOHNSON (CASUARINACEAE): A REVISED DESCRIPTION, WITH NOTES ON DISTRIBUTION AND HABITAT
}

\author{
by Richard Schahinger
}

(with one table, one text-figure, six plates and an appendix)

\begin{abstract}
SChahinger, R., 2002 (31:xii): Allocasuarina crassa L. Johnson (Casuarinaceae): a revised description, with notes on distribution and habitar. Papers and Proceedings of the Royal Society of Tasmania 136: 101-106. https://doi.org/10.26749/rstpp.136.101

ISSN 0080-4703. Threatened Species Unit, Department of Primary Industries, Water and Environment, GPO Box 44, Hobart, Tasmania 7001, Australia.

A revised description of the Tasmanian endemic Allocasuarina crassa L. Johnson is given, and its distribution, habitat and conservation status discussed. A new key to the Allocasuarina species in Tasmania is provided.
\end{abstract}

Key Words: Allocasuarina crassa, Cape Pillar, Tasman Peninsula, she-oaks, fire.

\section{INTRODUCTION}

Theopportunity is taken here to provide a revised description of Allocasuarina crassa L. Johnson, and to give notes on its distribution and habitat. The impetus for the revision came in December 1997, when I came across a stand of 60-80 Allocasuarina trees of unusual form in the Tasman National Park in southeastern Tasmania. The largest of the trees resembled an old Dutch elm, with a stout trunk separating into several ascending branches (plates 1 and 2). The size and vestiture of the branchlet articles and the dimensions and character of the fruiting bodies ('cones') were consistent with those of the rare Allocasuarina crassa (Capes she-oak), a species known only from the Cape Pillar-Tasman Island area. However, the size of the trees - some with a diameter at breast height $(\mathrm{dbh})$ in excess of $1 \mathrm{~m}$ and heights greater than $10 \mathrm{~m}$ - was clearly at odds with the original description of $A$. crassa as a 1-2 $\mathrm{m}$ high shrub (Johnson 1989). In addition, the flaky bark of the older specimens was quite unlike any of the recognised species of Allocasuarina in Tasmania.

Discussions with Dennis Morris of the Tasmanian Herbarium established that the specimens were indeed attributable to $A$. crassa, but that the original description required some revision to accommodate the features described above.

\section{TAXONOMY}

Allocasuarina crassa L.Johnson, Fl. Australia 3: 194 (1989)

Usually dioecious shrub or small tree, 0.3-12 m high, prostrate or erect habit. Bark smooth, becoming flaky with age. Branchlets spreading to ascending, to $26 \mathrm{~cm}$ long; articles 8-26 mm long, 0.75-4.0 mm diam., smooth, with densely pubescent furrows; phyllichnia strongly rounded; teeth 6-9 (-12), slender, spreading to slightly recurved, usually not overlapping, $1-4 \mathrm{~mm}$ long, not marcescent*. Male spikes occasionally moniliform, $1.0-4.5 \mathrm{~cm}$ long, 3.54 whorls per $\mathrm{cm}$; bracteoles persistent; anthers $0.8-2.0 \mathrm{~mm}$ long. Cones long-cylindrical, sessile or on a peduncle to 3 mm long; cone body 15-52 mm long, 12-29 mm diam.; bracteolesobtuse to truncate, pyramidal protuberance slightly shorter than bracteole body. Samara 5-8 mm long, black. $\left({ }^{*}\right.$ marcescent $=$ withering without being shed $)$
Representative Specimens

Tasmania: Tasman Island, 26 September 1965, J. Thwaites (HO 92115)*; near Lunchtime Creek, Cape Pillar track, 14 April 1984, A. M. Buchanan (HO 77229); between the Blade and Cape Pillar, 4 December 1984, P. M. Buchanan (HO 92114); c. 9 km along track to Cape Pillar, just south of Corruption Gully, 22 February 1986, K. L. Wilson (HO 108752); Hurricane Heath, Cape Pillar, 13 June 1993, F. Duncan (HO 303938); Arthurs Peak, Tasman Peninsula, 26 April 1997, R.B. Schahinger (HO 321732); Tasman Peninsula, E of Arthurs Peak, 7 April 1998, R. Schahinger (HO 325433); $300 \mathrm{~m}$ WSW of Perdition Ponds (Cape Pillar), 28 April 1998, R. Schahinger(HO 512433); northern end of Tornado Flat (Cape Pillar), 28 April 1998, $R$. Schahinger (HO 512434); southern end of Corruption Gully (Cape Pillar), 28 April 1998, R. Schahinger(HO 512435). ${ }^{*}(H O=$ Tasmanian Herbarium, Hobart)

A comparison of original and revised characters based on an examination of fresh material from a variety of habitats in the Cape Pillar area is presented in table 1. The upper range of most of these characters has been increased considerably by the present study, though some of these differences - anther length, for example - may be attributable in part to Johnson's (1989) use of dried material.

\section{NOTES}

Two other species of Allocasuarina co-occur with $A$. crassa over the latter's range: the small tree $A$. verticillata (Lam.) L.Johnson on Tasman Island, and the shrub A. monilifera (L.Johnson) L.Johnson at Tornado Flat and Arthurs Peak (fig. 1). Allocasuarina verticillatacan be readily distinguished from the other two species by its drooping foliage, pungent cones and hard fissured bark. Allocasuarina crassa is denser and coarser in appearance than $A$. monilifera, while it also differs from $A$. monilifera "in its larger and thicker articles with strongly pubescent furrows" (Johnson 1989: 159); $A$. monilifera has articles up to about $1 \mathrm{~mm}$ in diameter with glabrous furrows. Other differences are highlighted in a new key to the Tasmanian Allocasuarina species (appendix), developed in conjunction with Dennis Morris of the Tasmanian Herbarium in preparation for the revised edition of The Student's Flora of Tasmania. 


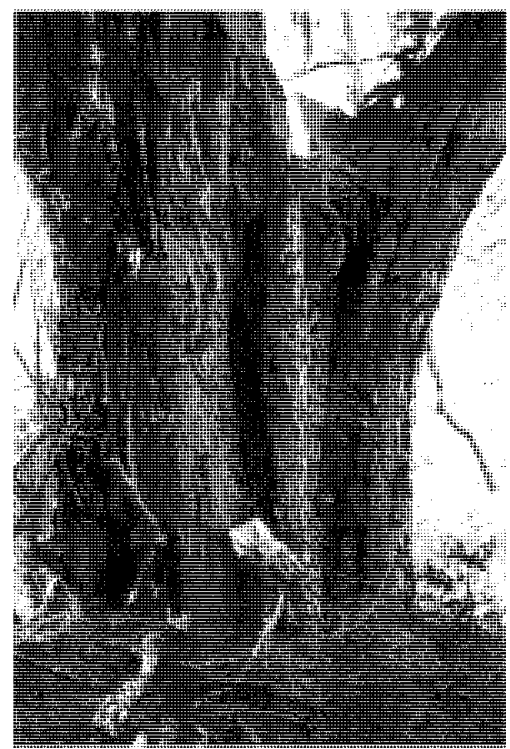

PLATE 1

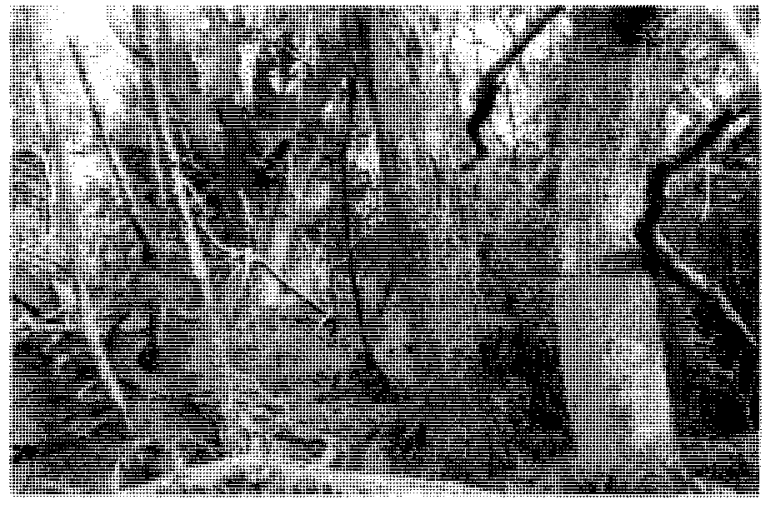

\section{PLATE 2}

Habit of A. crassa in a fire-protected slope near Tornado Ridge; two straight-trunked specimens right foreground, with a larger spreading specimen in background (trunk detail in pl. 1).

Tree-form of Allocasuarina crassa with diameter at breast height of $1.07 \mathrm{~m}$; note the flaky nature of the bark and the dense layer of needles at the base of the tree.

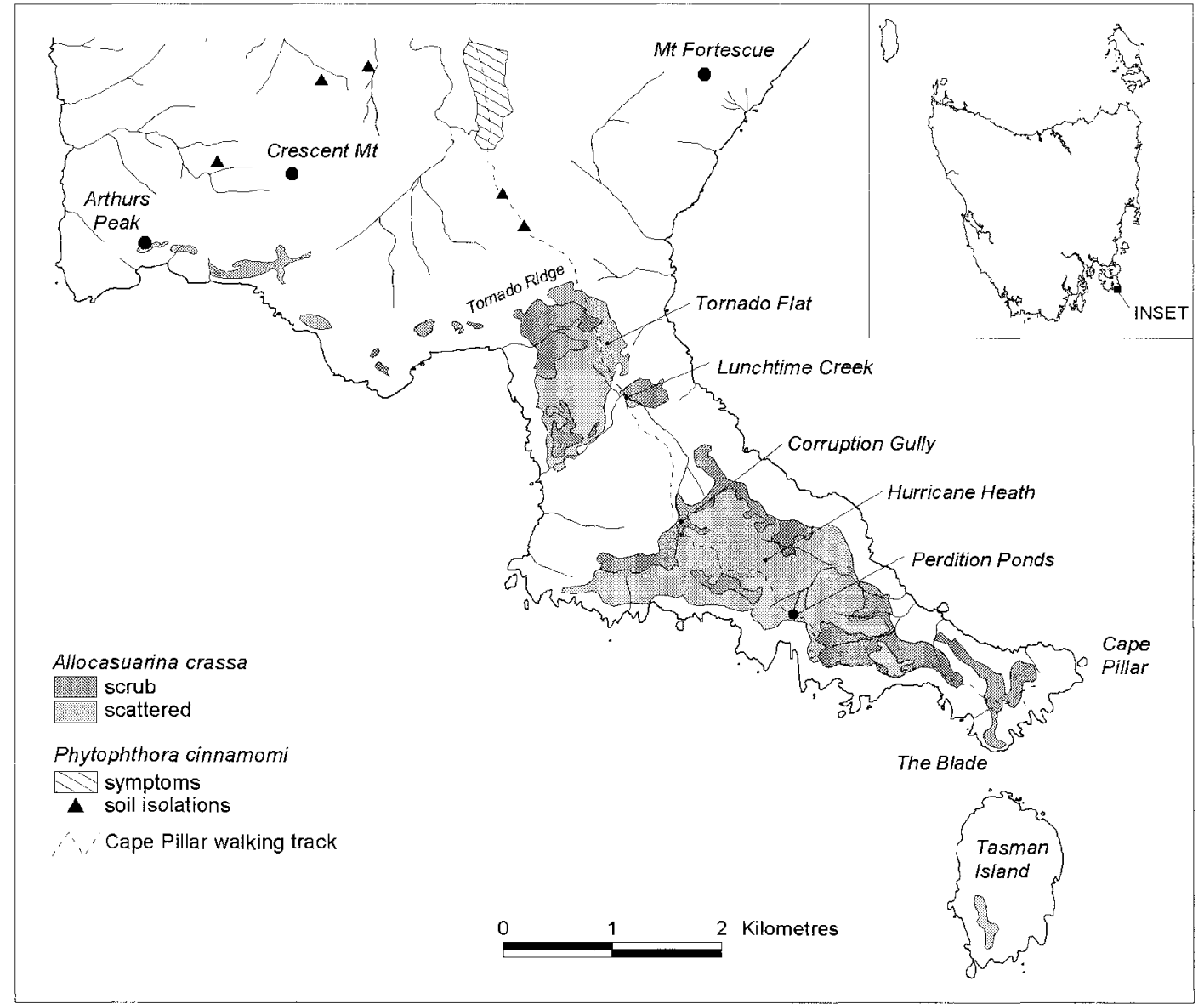

FIG. 1 - Distribution of Allocasuarina crassa in Tasmania. 
TABLE 1

Allocasuarina crassa: original and revised characters

\begin{tabular}{|c|c|c|}
\hline Character & Johnson (1989) & Revised \\
\hline habit & shrub, 1-2 $\mathrm{m}$ high & shrub to small tree, $0.3-12 \mathrm{~m}$ high \\
\hline bark & smooth & smooth, aging to flaky \\
\hline branchlets & to $17 \mathrm{~cm}$ long & to $26 \mathrm{~cm}$ long \\
\hline articles & $10-20 \mathrm{~mm}$ long, $1.2-2.0 \mathrm{~mm}$ diam. & $10-26 \mathrm{~mm}$ long, $1.2-4.0 \mathrm{~mm}$ diam. \\
\hline teeth & $7-10,1.1-3.0 \mathrm{~mm}$ long & $6-12,1.1-4.0 \mathrm{~mm}$ long \\
\hline male flower spike & c. $2 \mathrm{~cm}$ long, rately moniliform & $1.0-4.5 \mathrm{~cm}$ long, occ. moniliform \\
\hline anthers & $0.8-1.0 \mathrm{~mm}$ long & $0.8-2.0 \mathrm{~mm}$ long \\
\hline cone body & $15-34 \mathrm{~mm}$ long, $12-15 \mathrm{~mm}$ diam. & $15-52 \mathrm{~mm}$ long, $12-29 \mathrm{~mm}$ diam. \\
\hline
\end{tabular}

\section{DISTRIBUTION}

Allocasuarina crassa is now believed to be confined to an area on the Tasman Peninsula between Arthurs Peak and Tasman Island (fig. 1). Surveys by the author during 1997-2001 showed $A$. crassa to be a common element of the dolerite cliff vegetation between Arthurs Peak and Tornado Flat, well removed from the species' previously recorded range. Walking south along the Cape Pillar track A. crassa is first encountered in Eucalyptus tenuiramis/E. obliquadamp forest just north of Tornado Flat, while on the Flat itself $A$. crassa occurs in closed heath/scrub. Further to the southeast $A$. crassa is a common component of the vegetation of the Cape Pillar plateau, and indeed dominates some areas. Allocasuarina crassa attains tree stature in a number of sheltered sites along the walking track, e.g., Lunchtime Creek in conjunction with Callitris rhomboidea (Oyster Bay pine), the southern end of Corruption Gully, and between The Blade and Cape Pillar (fig. 1). The species is also locally common on the southwestern corner of the Tasman Island plateau in dry heath and scrub.

\section{HABITAT}

Allocasuarina crassa ranges from a prostrate shrub growing on the windswept rocky slopes southwest of Perdition Ponds (pl. 3), through the more 'typical' shrub form found in heaths, to a shrub or small tree on the exposed southerlyfacing dolerite cliffs between Arthurs Peak and Cape Pillar (pl. 4), to the tree form described earlier in more sheltered areas.

The main stems of the Perdition Ponds plants are typically ground-hugging, with branches erect to about $30 \mathrm{~cm}$, and articles up to $4 \mathrm{~mm}$ in diameter. The cones are relatively squat and well hidden within the plant, while branchlets have a conspicuously striped appearance due to the dense pubescence of the article furrows and the glabrous article ridges (pl. 5).

At the other extreme, articles with diameters of little more than $1 \mathrm{~mm}$ are present on tree-form specimens in the sheltered Corruption Gully area. Such an article size is comparable to that of $A$. monilifera, though the presence of strongly pubescent article furrows is again consistent with $A$. crassa. The flaky bark associated with the tree form of $A$. crassa would seem to be purely a function of age, as evidenced by the range of specimens shown in plates 1 and 2 .

\section{CONSERVATION STATUS}

Allocasuarina crassa is currently listed as rare in the Tasmanian Threatened Species Protection Act 1995. The taxon continues to qualify for rare under criterion B of the Act, viz., "Species subject to stochastic risk of endangerment because of naturally small population size (extent of occurrence $<2000 \mathrm{~km}^{2}$ )". Population characteristics are: (1) linear extent: $10.2 \mathrm{~km},(2)$ extent of occurrence: $20 \mathrm{~km}^{2},(3)$ area of occupancy: -400 ha, (4) number of mature individuals: (O) 100,000. The taxon has been found only in the Tasman National Park in southeastern Tasmania.

A number of $A$. crassa plants may have been destroyed during vegetation clearance on Tasman Island in the early 1900 s when the Tasman lighthouse was built. Since the demanning of the lighthouse in 1977 - and the subsequent cessation of slashing and of grazing by sheep - the vegetation has begun to re-establish itself, and $A$. crassa is now present in significant numbers. However, ongoing threats to $A$. crassa over its entire range include an inappropriate fire regime, and death through infection by the exotic soil-borne plant pathogen Phytophthora cinnamomi.

Barker (1994) found that A. crassa was moderately susceptible to $P$. cinnamomi in laboratory conditions and, given $A$. crassa's localised distribution, considered a "vulnerable" status to be more appropriate than "rare". The Tasmanian Parks and Wildlife Service established a washdown point at Lunchtime Creek on the Cape Pillar walking track in line with Barker's recommendations, ostensibly to restrict the movement of $P$. cinnamomi from known infestations to the Cape proper (fig.1; with protection of $A$. crassa and the susceptible endemic shrubs Epacris marginata and Epacris myrtifolia in mind). Allocasuarina crassa has yet to display symptoms of $P$. cinnamomi infection in the field (as at May 2002), and while these observations are comforting, the rarity of the species does mean that the present precautionary approach to walker hygiene on the Cape should be maintained.

Allocasuarina crassa is a serotinous species, storing its seed in cones in the canopy until fire causes its release. Most of the $A$. crassa scrubs observed on Cape Pillar are even-aged, with little sign of continuous recruitment (Rollins 1999). If an area happened to be burnt and then burnt again before plants had time to produce fruit, then $A$. crassa could be eliminated. This scenario is considered to be extremely unlikely, however, because of $A$. crassa's presence 


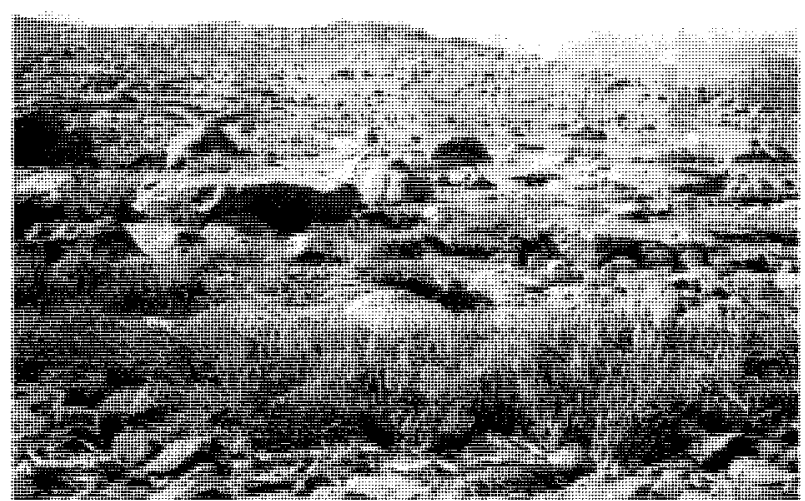

PLATE 3

Prostrate A. crassa on the rocky exposed slopes to the southwest of Perdition Ponds, Cape Pillar.

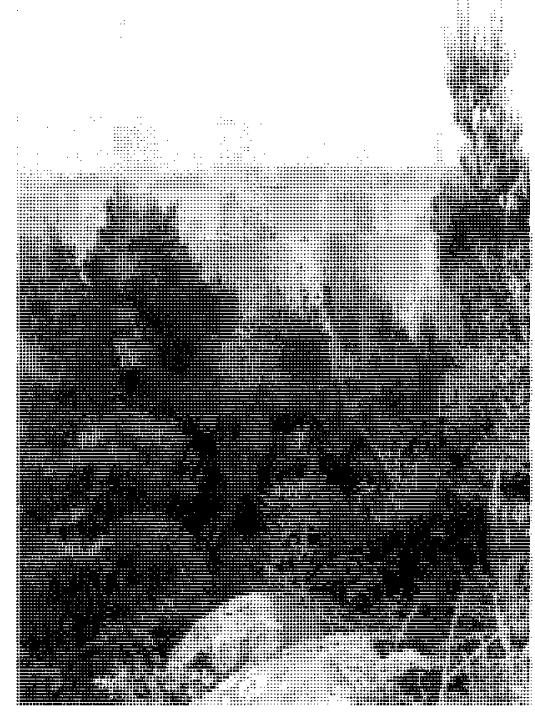

PLATE 4

Shrub-form of A. crassa on the cliff-tops to the east of Arthurs Peak, with Mt Brown and Cape Raoul in the background.

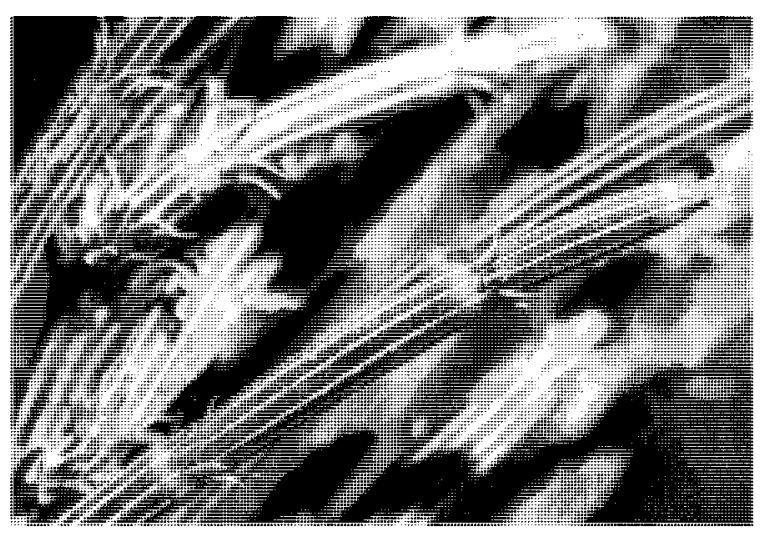

PLATE 5

Detail of A. crassa branchlets showing the distinctive pubescent article furrows and long spreading 'teeth'. in such a variety of habitats, including numerous fireprotected niches in the rugged dolerite cliff-faces that bound the Cape. Indeed, it is worth noting that much of the Cape has not been burnt for decades, some areas possibly not for centuries. In the late 1970s, however, a fire did burn about 60 ha of heath and scrub in the Perdition Ponds area, including 10 ha of scrub previously dominated by $A$. crassa (pl. 6); recovery has been very slow in this exposed area, with areas formerly supporting tall scrubs now reduced to $1.0-1.5 \mathrm{~m}$ heaths.

\section{DISCUSSION}

The disparate forms of $A$. crassa observed in the Cape Pillar area - that is, prostrate shrub to small tree - can be interpreted as a simple response to differing environmental pressures. Variables such as fire history, degree of exposure, topography, drainage, soil depth and fertility have combined to produce a diverse range of microhabitats (Brown $8 x$ Duncan 1989), with species' growth patterns responding accordingly. Indeed, both Banksia marginata (Honeysuckle) and Leptospermum scoparium (Manuka or Tea-tree) display similar variability in the Cape Pillar area.

What makes $A$. crassa noteworthy is its capacity to dominate vegetation on much of the Cape Pillar plateau. Given an extended period without fire, say $60-80$ years, $A$. crassa may form almost monotypic low forests; such areas can be readily mapped from aerial photographs due to their dark signature (pl. 6). The ground beneath these forests tends to be blanketed with a thick carpet of she-oak needles (pl. 1), and in consequence the ground layer is sparse and species-poor. The stand of $A$. crassa represented by the massive specimen shown in plate 1 most likely represents a successional endpoint in the continued absence of fire. Contributing factors include the site's southeasterly aspect and the development of a buffer of predominantly broadleafed species - species such as native laurel (Anopterus glandulosus), dragon heath (Richea dracophylla), dogwood (Pomaderris apetala) and stinkwood (Zieria arborescens) between the $A$. crassa trees and the adjacent pyrogenic eucalyptus-dominated forests. An analogous situation exists in the lee of nearby Crescent Mountain (fig. 1), where a small patch of relict rainforest dominated by myrtles (Nothofagus cunninghamii) has survived.

The $A$. crassa low forests on the Cape Pillar plateau occupy areas that are relatively well-drained. Leptospermum glaucescens (soft-fruited tea-tree) may co-dominate with $A$. crassa in sandier areas (along with sub-dominants Banksia marginata and Leptospermum scoparium), and may dominate completely in some areas due to its ability to grow faster and taller than other large shrub species (Kirkpatrick \& Harris 1999). A 50-year fire-free period could see the greater proportion of the Cape Pillar plateau dominated by just these two species; the active use of fire for ecological purposes by the managers of the Tasman National Park will inevitably be a lively topic for discussion in the not too distant future.

\section{ACKNOWLEDGEMENTS}

Many thanks to Dennis Morris, Alex Buchanan and Andrew Rozefelds of the Tasmanian Herbarium for their assistance during the evolution of this paper, with particular thanks to 

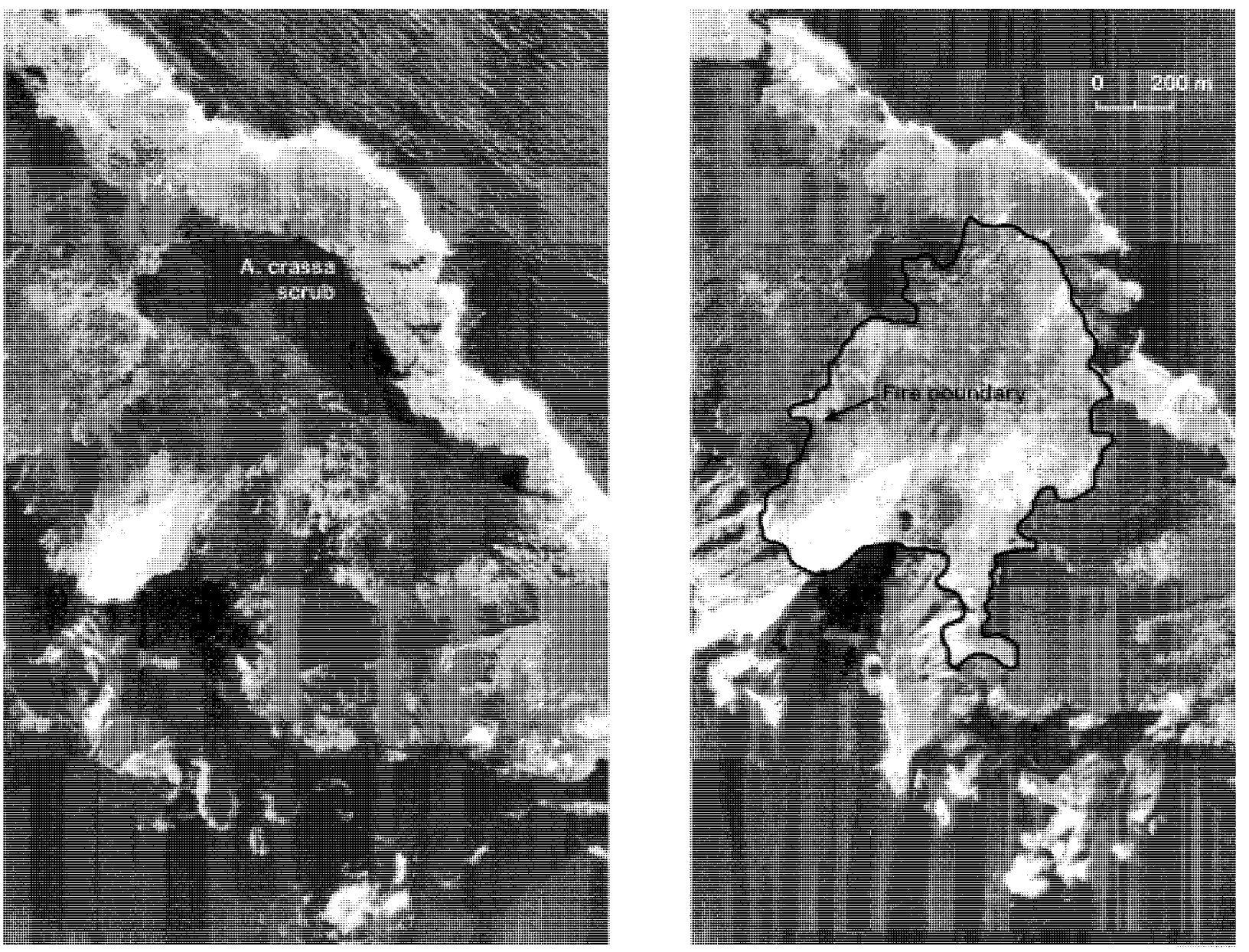

PLATE 6

Aerial photographs of the Perdition Ponds area showing scrubs dominated by A. crassa and the impact of fire; left panel, 18 April 1975, right panel, 28 February 1980.

Dennis Morris for allowing the use of the key to the

Tasmanian Allocasuarina species.

\section{REFERENCES}

BARKER, P.C.J., 1994: Phytophthora cinnamomi: the Susceptibility and Management of Selected Tasmanian Rare Species. Forestry Tasmania and Australian Nature Conservation Agency.

BROWN, M.J. \& DUNCAN, F., 1989: The vegetation of Tasman Peninsula. In Snith, S. J. (Ed.): Is History Enough? Past, Present and Future Use of the Resources of Tasman Peninsula. Royal Society of Tasmania, Hobart: 33-50.
JOHNSON, L.A.S., 1989: Flora of Australia 3: 194. Australian Government Publishing Service, Canberra.

KIRKPATRICK, J.B. \& HARRIS, S., 1999: The Disappearing Heath Revisited. Tasmanian Environment Centre Inc., Hobart.

ROLLINS, E., 1999: Population Biology and Vital Attributes of Threatened Serotinous Species. Honours thesis, University of Tasmania, Hobart.

(accepted 9 December 2002) 


\section{APPENDIX \\ Key to the Tasmanian Allocasuarina species (Morris, in prep.)}

1 Branchlets strongly drooping, minutely roughened; articles $8-40 \mathrm{~mm}$ long, furrows pubescent; cones cylindric to almost globular; cone valves prominent, their margins along the line of opening

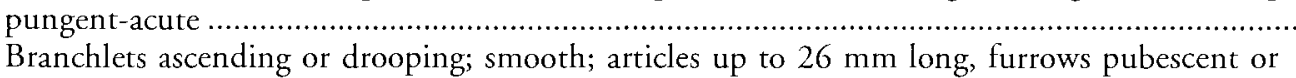
glabrous; cones ovoid to cylindric; cone valves with margins along the line of opening rounded or bluntly pointed

2 Phyllichnia with a median groove along their length; furrows occasionally minutely pubescent; shrub local in the northeast ............................................................................................................. A. paludosa Phyllichnia rounded or angular, without a median groove; furrows pubescent or glabrous .............................. 3

3 Article furrows densely to sparingly pubescent ............................................................................... 4 Article furrows usually glabrous, occasionally sparingly pubescent in basal articles of the branchlets ................ 5

4 Shrub or small tree to $15 \mathrm{~m}$ high; articles $3-10 \mathrm{~mm}$ long, $0.4-1.0 \mathrm{~mm}$ in diameter; teeth 6-8, $0.3-0.9 \mathrm{~mm}$ long, appressed to slightly spreading; bark fissured; widespread in northern and Shrub or small tree to $12 \mathrm{~m}$ high; articles $8-26 \mathrm{~mm}$ long, $0.75-4.0 \mathrm{~mm}$ in diameter; teeth $6-12$ 1-4 $\mathrm{mm}$ long, spreading or recurved; bark smooth or flaky; restricted to the Cape Pillar and

Tasman Island area of the Tasman Peninsula

5 Usually monoecious shrub 1-5 m high; articles usually 5-9 $\mathrm{mm}$ long, teeth 5-10 A. monilifera Usually dioecious shrub or tree to $8 \mathrm{~m}$ high; articles up to $18 \mathrm{~mm}$ long, teeth $7-9$

6 Usually erect \pm fastigiate small tree to $8 \mathrm{~m}$ high; cones $1.5-6.0 \mathrm{~cm}$ long; restricted to dolerite substrates in the Wellington Range, Snug Tiers and Bruny Island Usually \pm spreading shrub to $6 \mathrm{~m}$ high; cones $1-3 \mathrm{~cm}$ long; King Island, western Tasmania and the Central Highlands

Terminology (after Johnson 1989): the branchlets of Allocasuarina species are articulate, with several short basal articles and 1-numerous elongated articles. 'Teeth' refer to the reduced leaves at the apex of each branchlet article (see pl. 5). Each article has as many ridges (phyllichnia) as there are teeth; the phyllichnia are separated by furrows that may be obviously pubesecent or glabrous. 